\title{
Empirical Research on the Effect of Internal Capital Market Efficiency from Chinese A Shares Listed Companies ${ }^{*}$
}

\author{
Bin ZHANG ${ }^{1, a,{ }^{*}}$ \\ Business college, Yang Zhou University, Yang Zhou, China, 225002 \\ Yzdxzb@163.com \\ ${ }^{*}$ Corresponding author
}

Keywords: internal capital market efficiency, listed companies, segment information

\begin{abstract}
The paper makes the empirical analysis on factors affecting the A -share listed company's internal capital market efficiency, the study found that in the related factors of corporate governance, control and cash flow rights are associated with the internal capital market positively; the nature of ultimate shareholder and internal capital market efficiency have negative correlation; diversification and internal capital market efficiency levels are significantly correlated; The scale of internal capital and the efficiency of internal capital markets have positive correlation; Internal financial intermediaries and internal capital market efficiency are positively correlated.The results have the guiding significance for understanding and improving internal capital market efficiency of China's listed companies.
\end{abstract}

\section{Introduction}

In China, the inefficient allocation of resources has always been a serious problem. A -share listed companies are highly representative as a major part of China's listed companies. However, due to segment data is difficult to obtain, few scholars use A-share listed companies as the research subjects of internal capital market efficiency before. This article select A-share listed companies as research subjects in order to obtain the conclusions reflecting the current situation of China's internal capital market efficiency.

The rest arrangements of the paper are as follows: the second part is a literature review; the third part is the theoretical analysis and hypotheses; the fourth part is the research design; the fifth part is empirical analysis; the sixth part is the conclusions .

\section{The literature review}

Theoretical studies on the influencing factors of the internal capital market efficiency, Huang fuguang( 2002 ) [4]thinks that the ultimate controlling stake and interest is an important factor of allocative efficiency. Xu qiting ( 2008 ) [5] pointed out that the internal capital market efficiency and CEO decision-making capacity, capital allocation decision-making process and decision-technical level,the information structure of the organization, agency problems have a relationship, different combinations of elements will bring a different results of internal resource allocation. Lu JianXin ( 2008 ) [6] thinks that the organizational structure, the degree of improvement of corporate governance, external capital environment, management incentives are internal and external factors of the existence and play of internal capital market allocation efficiency,

\footnotetext{
* This paper is the research results of Humanities and Social Sciences project under Ministry of Education, named "Research on the efficacy of Segment Information of Chinese Listed Companies" (09YJA790175).
} 
and he has a deep discussion about these factors on the impact of internal capital market efficiency. Wang fengjuan and Wang yakun( 2009 ) [7] analyzed the enhancement of the Group's internal financial institution 's on internal capital market efficiency, they point that the financial sector is not only the intermediaries operating platform of internal capital markets, but also can help businesses group allocate resources better by internal borrowing rates .

Zhou Yean etc (2003 )[8] analyzed the existence of internal capital markets of China's listed companies using Hualian Supermarket backdoor listing as an example . they pointed out that corporate decision-makers will take the initiative to construct the internal capital market and make use of internal capital market and external capital markets complementary or alternative to create value in the transition and emerging markets.Zeng Yamin et al (2005) made the empirical results to show that China 's motives for equity acquisitions are not building the internal capital market, but the abuse of free cash flow. Jian Zhangzhang ( 2006 ) [9] study that high-tech enterprises and the cash flow position of external capital markets have impact on the allocation efficiency of internal resource, the results show that the degree of diversification and a cash inflow and outflow of the company with external capital markets were negatively related.Xu Qiting ( 2008 )[5] and Lu Jianxin ( 2008 )[6] also think the internal capital market is invalid for the " Family " companies. They had a further study on the factor affecting the efficiency of internal capital markets, the method is studying the relevance between internal capital market efficiency and the excess value firstly, then multivariate regression analysis using the excess value as the dependent variable, at last,we can know the direction and degree of each factor on the impact of internal capital market .

\section{The theoretical analysis and hypotheses}

\section{Corporate governance and internal capital market efficiency}

Because of the special ownership structure, especially the shares of listed companies generally concentrate, shareholder can affect and decide the company's resource allocation with voting rights and control rights. Ownership concentration can effectively restrict the moral risk of management and reduce agency costs caused by dispersed ownership, which can make up less incentives.

The separation of control rights and cash flow rights will lead to inconsistent interests of controlling shareholder and other shareholders, which is the essential reason why controlling shareholders make predatory interests. But the predatory behavior of the controlling shareholder caused by control rights and cash flow rights separation just reduced the amount of available funds of listed companies, but does not necessarily affect the company's internal capital allocation. While external regulation can limit controlling shareholders' hollowed behavior.

State-owned enterprises often have political goals such as full employment, which interfere business management. The management of state-owned enterprises who aren't elected but the executive appointments do not have the management capacity of enterprises, so the management are more inclined to pursue social and political goals rather than the maximizing of shareholder value .

Smaller size of the board is more efficient. Board size is too large, mutual communication and coordination among its members will also increase the difficulty, and agency problems will intensify.

At present, China's system of independent directors have some problems. Independent directors' special status, limited working hours and limited depth of the company's business lead to play functions in decision-making difficultly.

Our requirements on two major functional separation of chairman and general manager are needed for corporate governance and internal control. Two major functional separation is good to 
balance the executive power and decision-making power, but it will cause the board dummy and chairman is sidelined. Two hats-one will cause excessive concentration of decision-making and lead to wrong decisions, but helps to acquire more reliable information to make decision-making more scientific. There isn't necessary connection between the efficiency of resource allocation with two hats-one .

Board meetings are the main form of collective enterprise decision-making, and a perfermance of diligence performance of the Board. Therefore, an appropriate increase in the number of meetings of the Board and the decision-making programs can be communicated more fully, it will help improve scientific decision-making, but too much of Directors meetings mean that the Board's decision is likely to be weak and often indecisive, or in response to company performance decline.

Based on the above analysis, we propose the following hypothesis :

Assumption1: The higher proportion of shareholding of the ultimate controlling shareholder, the higher efficiency of the internal capital market.

Assumption2: The higher proportion of cash flow rights of the ultimate controlling shareholder, the higher efficiency of the internal capital market .

Assumption3: Ultimate Controlling Shareholders' separation of ownership and control rights is not associated with the internal capital market efficiency.

Assumption4: Compared with non-state holding company, the company whose nature of the ultimate shareholder is state-owned has less efficient internal capital markets.

Assumption5:Board size and efficiency of the internal capital market negatively correlated.

Assumption6: The proportion of independent directors in the boardroom has nothing to do with the internal capital market efficiency.

Assumption7: Two hats-one or not has nothing to do with internal capital market efficiency.

Assumption8: The number of board meetings and internal capital market efficiency are in an inverted U-shaped correlation.

\section{Diversification and internal capital market efficiency}

The performance of the company is the results of the quantitative allocation of resources, there are two ways of allocation of resources: focused resource allocation and distributed resource allocation, two ways of allocation of resources form two companies operating strategy ultimately: specialization and diversification. Research diversification, corporate performance and the value relevance of the company, which can't ignore this important part of the efficiency of resource allocation.

Relative to non-diversified companies, diversified companies have advantages of controlling or avoiding risks, high efficiency configuration and more external financing opportunities. Meanwhile, the diversified businesses are growing, because the companies' energy has invested substantially in the diversification, and incentives, information and supervision would appear to be relatively weak, thus affecting information transfer effect, increasing agent question, the phenomenon of " rent-seeking "and "cross-subsidization " intensified, the leadership will make the wrong decisions. However, the degree of diversification of China's listed companies in general is not high, it may not yet reached the degree of negative correlation with the internal capital market, so propose the hypothesis:

Assumption9:The degree of diversification and internal capital market efficiency were positively correlated. 


\section{Internal capital, the internal financial intermediaries and the internal capital market efficiency}

If the capital scale of the enterprises is small, it will limit the advantage of resources allocation. Many positive NPV projects can't get adequate funding, the limited funds supply barely the existing projects . Expand the size of the internal capital markets, it can promote headquarters in allocation of resources between segments, through inter-segment competition, headquarters will allocate resources to get the most optimal configuration, and it ultimately help to improve the efficiency of the internal capital market. However, the size of internal capital market is too large ,it will also bring some negative issues, for example, if the headquarters are lack of capacity in the management or have limitations of access to information and the complexity of proxy issues, etc. , they are likely to lead to the decrease of internal capital market efficiency. Based on the above analysis, The paper think that there are an inverted U-shaped correlation between the size of internal capital and the efficiency of internal capital market. However, the relative size of listed companies in China at this stage are not too great, there is no large scale of internal capital market, thus this paper propose the following assumptions:

Assumption10:The scale of internal capital and the efficiency of internal capital market are positively correlated .

In the initial stage of the formation of internal financial intermediaries, the aim is to solve the funding problem of member of group. Formation of internal financial intermediaries enhance liquidity on the one hand and reduce the burden on external financing, on the other hand make the funds of positive cash flow project can be guaranteed. Financial intermediation is a combination of financial management and financial management, its role is to pay and regulate internal funds. The overall strategy of enterprises can convey by setting the internal financial targets, then financial intermediaries imple the strategic objectives to each segment and regulate the operating of segment funds, which is good to achieve the overall goal.Based on the above analysis, the paper propose the following assumptions:

Assumption11:Compared with business without financial intermediary, business with financial intermediary has the higher the efficiency of the internal capital market.

\section{The study design}

\section{Sample and data}

This paper select 516 samples from 2007 to 2010 , exclude 103 study samples the required information is incomplete, and get 413 samples meeting the requirements. the data of empirical research in this section are from the sample company's annual report from 2007 to 2010 , all the data were extracted directly from the calculation of annual reports by hand .

4.2 variables and measurement, as shown in Table 1. 
Table 1 Related variables explained

\begin{tabular}{|c|c|c|c|}
\hline \multicolumn{2}{|r|}{ Variables } & \multirow{2}{*}{$\begin{array}{c}\text { Symbol } \\
\text { APS }\end{array}$} & Description and calculation \\
\hline $\begin{array}{l}\text { variables } \\
\text { explaned }\end{array}$ & $\begin{array}{l}\text { Profit sensitivity } \\
\text { coefficient }\end{array}$ & & $\begin{array}{l}\text { Reflect the efficiency of internal capital } \\
\text { market }\end{array}$ \\
\hline \multirow{11}{*}{$\begin{array}{l}\text { explanatory } \\
\text { variables }\end{array}$} & $\begin{array}{l}\text { The proportion of } \\
\text { control right }\end{array}$ & VR & $\begin{array}{l}\text { Calculate based on the lowest percentage of } \\
\text { shareholding of each control chain } \\
V R=D+\sum \operatorname{Min}\left(I_{k 1}, I_{k 2} \ldots I_{k t}\right),(1 \leq t \leq m)\end{array}$ \\
\hline & $\begin{array}{l}\text { The proportion of } \\
\text { cash flow rights }\end{array}$ & CFR & $\begin{array}{l}\text { The sum of product of the shareholding ratio of } \\
\text { each control chain } C F S=D+\sum \prod I_{k t},(\mathrm{~m}>1)\end{array}$ \\
\hline & $\begin{array}{l}\text { Separation coefficient } \\
\text { of control rights and } \\
\text { cash flow rights }\end{array}$ & SR & $S R=V / C F$ \\
\hline & $\begin{array}{l}\text { The nature of ultimate } \\
\text { shareholders }\end{array}$ & FSH & The state-owned enterprise is 1 , or 0 \\
\hline & $\begin{array}{l}\text { The number of board } \\
\text { directors }\end{array}$ & $\mathrm{DN}$ & The company annual report disclosure \\
\hline & $\begin{array}{l}\text { The proportion of } \\
\text { independent directors }\end{array}$ & IND-R & $\begin{array}{l}\text { The ratio of the number of independent } \\
\text { directors and the number of all the directors }\end{array}$ \\
\hline & $\begin{array}{l}\text { Two-jobs one dummy } \\
\text { variable }\end{array}$ & TP & When manager is chairman,too. TP is 1 , or 0 . \\
\hline & $\begin{array}{l}\text { The number of board } \\
\text { meeting }\end{array}$ & BMT & The number of the board meetings \\
\hline & $\begin{array}{l}\text { The degree of } \\
\text { diversification }\end{array}$ & DIV & $\begin{array}{l}\text { The degree of diversification=The total amount } \\
\text { of sales/The largest corporate management } \\
\text { project sales }\end{array}$ \\
\hline & Internal capital scale & $\mathrm{S}$ & Total assets \\
\hline & $\begin{array}{l}\text { Internal financial } \\
\text { intermediaries }\end{array}$ & IFI & $\begin{array}{l}\text { The existence of financial intermediaries is } 1 \text {,or } \\
0 \text {. }\end{array}$ \\
\hline $\begin{array}{r}\text { Control } \\
\text { variables }\end{array}$ & $\begin{array}{l}\text { The rate of assets } \\
\text { liabilities }\end{array}$ & $\mathrm{L} / \mathrm{S}$ & \\
\hline
\end{tabular}

\section{The empirical analysis}

\section{Descriptive Statistics}

The result of descriptive statistics showed that the mean and median of profits sensitivity coefficients are positive, indicating that internal capital market is overall effective in 2010. The median of diversified index is 1.825225085 , the mean is 2.101707 , which means that the degree of diversification of the sample companies is not high.

\section{Multiple regression analysis}

\section{Corporate governance and internal capital market efficiency}

We made the regression on the ultimate shareholders characteristics and profit-sensitive characteristics, then gradually added the variables and established eight models, the results are in Table 3 and Table 4. 
Table2 Ultimate shareholder characteristics and internal capital market multiple regression

\begin{tabular}{|c|c|c|c|c|}
\hline & Model 1 & Model 2 & Model 3 & Model 4 \\
\hline C & -0.00110 & -0.00075 & -0.00143 & -0.00152 \\
& $(-1.22367)$ & $(-0.86193)$ & $(-1.32013)$ & $(-1.29177)$ \\
VR & $0.00471^{* *}$ & & $0.00472^{* *}$ & \\
& $(2.26576)$ & & $(2.26461)$ & \\
CFR & & $0.00416^{*}$ & & $0.00456^{* *}$ \\
& & $(1.89621)$ & & $(2.06521)$ \\
SR & & & 0.00027 & 0.00050 \\
& & & $(0.55014)$ & $(0.97371)$ \\
\hline Adjustmentof R & 0.03201 & 0.02034 & 0.02654 & 0.01993 \\
F & $5.13368^{* *}$ & $3.59560^{*}$ & $2.70373^{*}$ & 2.27110 \\
\hline
\end{tabular}

Note: $*, * *, * * *$ denote the significance of $10 \%, 5 \%$ and $1 \%$ (the following is same ).

Model one is control rights and profit -sensitive coefficients regression. The data show that control rights and profit -sensitive coefficient have positive correlation, and passed the significance test of $5 \%$, indicating that the greater the control rights, the higher the internal capital market efficiency .

Model two is cash flow rights and profit-sensitive coefficients regression, the data show that the cash flow rights and profit-sensitive coefficient have positive correlation, and passed the significance test of $10 \%$, indicating that the greater the cash flow rights, the higher the internal capital market efficiency .

The $\mathrm{F}$ value of model one and model two is 5.13368 and 3.59560 ,they both passed the test of significance of $5 \%$ and $10 \%$ thus confirming the hypothesis 1 and hypothesis 2 . The explanatory power of model 3 and model 4 added control and cash flow separation coefficient has declined, the control rights and cash flow rights separation factor of the latter two models did not pass the significance test. After adding the nature of the ultimate shareholder and asset-liability ratio and the formation of model five and model eight, the results remain unchanged. This result supports the assumption 3, the separation of the ultimate shareholder control rights and cash flow rights does not result in the decrease of efficiency of resource allocation of listed companies .

Table 3 The multiple regression of ultimate shareholder characteristics and internal capital market

\begin{tabular}{|c|c|c|c|c|}
\hline & Model 5 & Model 6 & Model 7 & Model 8 \\
\hline C & -0.00005 & -0.00004 & 0.00119 & 0.00119 \\
& $(-0.03417)$ & $(-0.02510)$ & $(0.66829)$ & $(0.62155)$ \\
VR & $0.00410^{*}$ & & $0.00406^{*}$ & \\
& $(1.95815)$ & & $(1.93827)$ & \\
CFR & & 0.00371 & & 0.00361 \\
& & $(1.61003)$ & & $(1.56188)$ \\
SR & 0.00018 & 0.00036 & 0.00015 & 0.00033 \\
& $(0.36042)$ & $(0.70195)$ & $(0.30265)$ & $(0.63601)$ \\
FSH & $-0.00164 *$ & $-0.00157^{*}$ & $-0.00168^{*}$ & $-0.00161 *$ \\
& $(-1.79559)$ & $(-1.68202)$ & $(-1.83776)$ & $(-1.72882)$ \\
L/S & & & 0.00048 & 0.00022 \\
& & & $(0.14782)$ & $(0.02746)$ \\
\hline AdjustmentofR & 0.04383 & 0.03429 & 0.04442 & 0.03422 \\
F & $2.90980^{* *}$ & $2.47965^{*}$ & $2.45267 * *$ & $2.10733^{*}$ \\
\hline
\end{tabular}

Model 5 and model 6 is the result of adding shareholder nature. The data show that the nature of the ultimate shareholders and profit-sensitive coefficient have negative correlation and passed significance test of $10 \%$, indicating that listed company controlled by the government have poorer 
efficiency of internal capital market than listed companies controlled by non-government. After adding asset-liability ratio and the results remain unchanged, which proves the assumption 4 holds. This result is generally consistent with the study of domestic and foreign scholars about state-owned enterprises. This is because state-owned enterprises generally have political goals such as full employment,it will interfere with normal business operations, and management of state-owned enterprises are often not professional managers who do not have the necessary capacity to manage the enterprise, and state-owned enterprises have the absence of the owner and the lack of effective corporate governance mechanisms.

Model 7 and model 8 are the regression results added asset-liability ratio. The results showed that the explanatory power of the model fell, asset-liability ratio and profit -sensitive coefficient have very low correlation, indicating that the creditor does not play a governance role .

Based on the above analysis, the study on the relevance between characteristics of the board, executive ownership and internal capital market, deleted the control rights and cash flow rights separation factor and asset-liability ratio from the model, the results added the features of the board and executive ownership are shown in table 5.

Table 4 The regression results of board characteristics and managerial ownership

\begin{tabular}{|c|c|c|c|c|}
\hline & $\begin{array}{c}\text { Non } \\
\text { standardized } \\
\text { coefficient }\end{array}$ & $\begin{array}{c}\text { Standard } \\
\text { deviation }\end{array}$ & $\begin{array}{c}\text { The } \\
\text { standardized } \\
\text { coefficient }\end{array}$ & $\mathrm{t}$ \\
\hline C & 0.00059 & 0.00349 & & 0.16940 \\
VR & $0.00364^{*}$ & 0.00216 & 0.15419 & 1.68114 \\
FSH & $-0.00171^{*}$ & 0.00095 & -0.16699 & -1.79709 \\
DN & 0.00000 & 0.00016 & 0.00033 & 0.00338 \\
IND-R & -0.00190 & 0.00608 & -0.03081 & -0.31215 \\
TP & 0.00000 & 0.00053 & 0.00049 & 0.00542 \\
BMT & 0.00006 & 0.00009 & 0.06125 & 0.67510 \\
\hline Adjustment of R & \multicolumn{5}{|c|}{0.02340} \\
F & \multicolumn{5}{|c|}{1.42784} \\
\hline
\end{tabular}

The data show that the explanatory power of the model decreased after adding the directors characteristics, and the number of the Board, the proportion of the board, two jobs-one situation, the number of board meetings and profit sensitivity factor are not relevant. After using cash flow rights instead of control rights, the results remain unchanged.This conclusion proved assumption 6 and assuming 7,but assuming 5 and assuming 8 did not pass the inspection.

\section{Diversification and internal capital market efficiency}

The point of the paper think that our business diversification and internal capital market efficiency are positively correlated. Therefore in the model of this part, adding specialization ratio DIV reflecting the degree of diversity and the formation of model 10, the results are shown in Table 6. 
Table 5 The regression results of diversification and internal capital market efficiency

\begin{tabular}{|c|c|c|c|c|}
\hline & $\begin{array}{c}\text { Non } \\
\text { standardized } \\
\text { coefficient }\end{array}$ & $\begin{array}{c}\text { Standard } \\
\text { deviation }\end{array}$ & $\begin{array}{c}\text { The } \\
\text { standardized } \\
\text { coefficient }\end{array}$ & $\mathrm{t}$ \\
\hline C & -0.00135 & 0.00128 & & -1.05913 \\
VR & 0.00226 & 0.00217 & 0.09571 & 1.03947 \\
FSH & $-0.00154^{*}$ & 0.00089 & -0.15083 & -1.73910 \\
DIV & $0.00103^{*}$ & 0.00042 & 0.22465 & 2.45710 \\
\hline Adjustment of R & \multicolumn{4}{|c|}{0.08794} \\
F & \multicolumn{5}{|c|}{$5.01761^{* * *}$} \\
\hline
\end{tabular}

The data show that the nature of the ultimate shareholder and internal capital market efficiency have a significant negative correlation at the $10 \%$ level, the degree of diversification and internal capital market efficiency was positively correlated, and passed the significance test of 5\%. This conclusion verified the hypothesis 9.

Internal capital, the internal financial intermediaries and the internal capital market efficiency

On the basis of the model 10, the paper added variable to reflect the size of the internal capital market----total assets, and form model 11, the results are shown in Table 7.

Table 6 The regression results of total assets and internal capital market efficiency

\begin{tabular}{|c|c|c|c|c|}
\hline & $\begin{array}{c}\text { Non } \\
\text { standardize } \\
\text { d coefficient }\end{array}$ & $\begin{array}{c}\text { Standard } \\
\text { deviation }\end{array}$ & $\begin{array}{c}\text { The } \\
\text { standardized } \\
\text { coefficient }\end{array}$ & $\mathrm{t}$ \\
\hline C & -0.00163 & 0.00122 & & -1.34424 \\
VR & 0.00201 & 0.00206 & 0.08529 & 0.97572 \\
FSH & $-0.00183^{* *}$ & 0.00084 & -0.17942 & -2.17121 \\
DIV & $0.00098^{* *}$ & 0.00040 & 0.21513 & 2.47859 \\
S & $0.00053^{* * *}$ & 0.00014 & 0.31008 & 3.80701 \\
\hline Adjustment of R & \multicolumn{4}{|c|}{0.17877} \\
F & \multicolumn{4}{|c|}{$7.30275^{* * *}$} \\
\hline
\end{tabular}

The data show that total assets and profit-sensitive coefficient have positive correlation significantly at the level of $1 \%$, the assumption 10 holds and the explanatory power of the model is very strong. On this basis, adding the variable of internal financial intermediation, the formation of model 12, the results are shown in Table 8.

Table 7 The regression results of internal financial intermediaries and the internal capital market efficiency

\begin{tabular}{|c|c|c|c|c|}
\hline & $\begin{array}{c}\text { Non } \\
\text { standardized } \\
\text { coefficient }\end{array}$ & $\begin{array}{c}\text { Standard } \\
\text { deviation }\end{array}$ & $\begin{array}{c}\text { The } \\
\text { standardized } \\
\text { coefficient }\end{array}$ & $\mathrm{t}$ \\
\hline C & -0.00193 & 0.00120 & & -1.60340 \\
VR & 0.00030 & 0.00216 & 0.01272 & 0.13892 \\
FSH & $-0.00170 * *$ & 0.00083 & -0.16638 & -2.04360 \\
DIV & $0.00086^{* *}$ & 0.00039 & 0.18685 & 2.16806 \\
S & $0.00049 * * *$ & 0.00013 & 0.30543 & 3.81437 \\
IFI & $0.00202 * *$ & 0.00088 & 0.20387 & 2.29595 \\
\hline Adjustment of R & \multicolumn{5}{|c|}{0.20677} \\
F & \multicolumn{5}{|c|}{$7.51683 * * *$} \\
\hline
\end{tabular}

After adding the internal financial intermediaries, the explanatory power of the model increased, 
internal financial intermediaries and internal capital market efficiency are related positively and pass significance test of $5 \%$, the assumption 11 holds.

\section{Conclusions}

\section{Research conclusions}

This paper used our A-share multi-segment listed companies as samples from 2007 to 2010 , measured its internal capital market efficiency firstly; then from four aspects: corporate governance, diversity, internal capital,internal financial intermediaries, made on assumption to study the factors of internal capital market and obtain the following conclusions:

In the relevant factors of corporate governance, control rights and cash flow rights are associated with the internal capital market positively; The nature of ultimate shareholder and the internal capital market efficiency are negatively correlated; The level of diversification and internal capital market efficiency have a significant positive correlation; internal capital scale and internal capital market efficiency significant positive correlation;The internal financial intermediation and the internal capital market efficiency are positively correlated. The research results have the guiding significance for understanding and improving internal capital market efficiency of China's A-share listed companies.

\section{References}

[1] Yang Rui , financial arrangements and companies investments, the world economy, Section five, 1999

[2] Liang Lei, Wang Hongtao,the comparison of enterprise group development model and operational mechanism, Machinery Industry Press, 2003 edition

[3] Yang jinzhi,internal capital markets firm performance and private benefits of control - in Hua Tong Tianxiang Group, Accounting Research ,Section12,2006

[4] Huang guangfu,invalidity analyzes of controlled companies internal capital allocation, Finance Society, the Ninth Annual Conference Proceedings , 2002

[5] Xu qiting, internal capital market efficiency research - Empirical Analysis Based on Chinese Private Listed Companies , Economic Science Press, 2008 edition

[6] Lu Jianxin, theoretical review of internal capital markets, Peking University Press, 2008 edition

[7] Wang fengJuan,Wang Yakun,synergistic effect on domestic financial institutions in the allocation of resources, China's township enterprises Accounting, Section 1,2009

[8] Zhou Yean,Han Mei,listed company internal capital market research- Hualian Supermarket backdoor listing, Management World, Section 11,2003

[9] Jian Zhangzhang, An Empirical Analysis of the efficiency of the internal capital market allocation, Master Thesis, 2006

[10] Wangfeng Juan, internal capital market efficiency research - $\mathrm{H}$ shares as a sample, Economic Science Press, the first edition, August ,2009 